\title{
Ultrastructure and Self-cleaning Function of Moth (Notodontidae) and Butterfly (Lycaenidae) Wings
}

\section{Yan FANG, Gang SUN*, Jing-shi YIN, Wan-xing WANG and Yu-qian WANG}

School of Life Science, Changchun Normal University, Changchun 130032, China

${ }^{*}$ Corresponding author

Keywords: Ultrastructure, Self-cleaning, Wettability, Moth, Butterfly, Biomaterial.

\begin{abstract}
The microstructure, hydrophobicity, adhesion and chemical composition of the butterfly and moth wing surfaces were investigated by a scanning electron microscope (SEM), a contact angle meter, and a Fourier transform infrared spectrometer (FT-IR). Using ground calcium carbonate (heavy $\mathrm{CaCO}_{3}$ ) as contaminating particle, the self-cleaning performance of the wing surface was evaluated. The wing surfaces, composed of naturally hydrophobic material (chitin, protein, fat, etc.), possess complicated hierarchical micro/nano structures. According to the large contact angle (CA, 148.3 156.2 ${ }^{\circ}$ for butterfly, 150.4 154.7 for moth) and small sliding angle (SA, 1 $3^{\circ}$ for butterfly, $1 \sim 4^{\circ}$ for moth), the wing surface is of low adhesion and superhydrophobicity. The removal rate of contaminating particle from the wing surface is averagely $88.0 \%$ (butterfly wing) and $87.7 \%$ (moth wing). There is a good positive correlation ( $\mathrm{R}^{2}=0.8385$ for butterfly, 0.8155 for moth) between particle removal rate and roughness index of the wing surface. The coupling effect of material element and structural element contributes to the outstanding superhydrophobicity and self-cleaning performance of the wing surface. The wings of flying insect can be potentially used as templates for biomimetic preparation of biomedical interfacial material with multi-functions.
\end{abstract}

\section{Introduction}

Wettability is basically determined by chemical composition (free energy) and microstructure (roughness) of the surface [1 3]. The interfacial material with special properties and functions is attracting more and more attention due to the wide application in industrial, agricultural, military and biomedical fields. After long-term natural evolution and selection, many plants and animals have possessed special (anti-adhesive, anti-corrosive, anti-wetting, anti-icing, anti-wearing, etc.) body surfaces to adapt to the environment. Inspired by the wettability of various bio-surfaces, lots of biomimetic materials have been artificially prepared [4 6]. Insect is not only the unique flying invertebrate, but the animal with the most species, the largest number and the most widespread distribution on the earth. As one of the most complicated three-dimensional periodical substrates in nature, insect body surface has been employed as a popular fabrication template because of its superior characteristics [7]. Using ground calcium carbonate as contaminating particle, in this work the self-cleaning performance of insect in Lepidoptera (butterfly and moth) was evaluated. The mechanism of wettability and self-cleaning property was discussed from the perspective of biological coupling. The results can bring insight for design and preparation of novel interfacial material and biomedical self-cleaning surface. 


\section{Materials and Methods}

\section{Materials}

The specimens of butterfly (ten species in Lycaenidae) and moth (ten species in Notodontidae) were collected in Changchun City, Dalian City, Harbin City and Jilin City of Northeast China. The wings were cleaned, desiccated and flattened, then cut into $5 \mathrm{~mm} \times 5 \mathrm{~mm}$ pieces from the discal cell (Fig. 1). The distilled water for CA and SA measurements was purchased from Tianjin Pharmaceuticals Group Co. Ltd., China. The volume of droplet for CA and SA measurement was $5.0 \mu \mathrm{l}$, the volume of droplet for measurement of $\mathrm{CaCO}_{3}$ removal rate was $9.0 \mu$. The average diameter of $\mathrm{CaCO}_{3}$ particle was $5 \sim 10 \mu \mathrm{m}$.

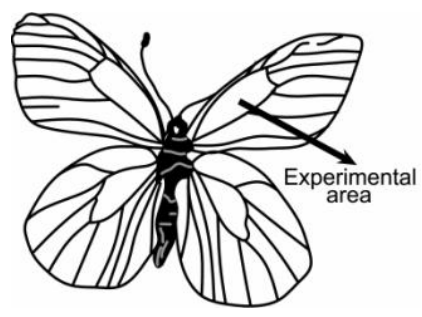

Figure 1. The experimental area of the wing surface

\section{Methods}

\section{Characterization of the Micro/nano Structure}

After gold coating by an ion sputter coater (Hitachi E-1045, Japan), the wing pieces were observed and photographed by a SEM (Hitachi SU8010, Japan). Using Photoshop software, the microstructural parameters of the wing were measured in SEM images.

\section{Measurements of the Wetting Angles}

Using an optical CA measuring system (DataPhysics OCA20, Germany), the CA of water droplet on the wing was measured by sessile drop method at room conditions of $25 \pm 1{ }^{\circ} \mathrm{C}$ and relative humidity of approximately $80 \%$. The sliding angle (SA) of water droplet was measured along the direction from base to terminal end of the wing. The water droplet was dripped on the sample table in a horizontal position, then the inclination degree of the table was raised $1^{\circ}$ each time until the droplet rolled off freely. The inclination degree of the table was recorded as the SA value.

\section{FT-IR Measurement}

After grinding finely, 5 8 mg of wing samples were mixed homogeneously with 200 $\mathrm{mg}$ of $\mathrm{KBr}$ and pressed into a thin slice. The absorbance was measured by means of FT-IR (Nicolet FT-IR200, USA). The chemical composition of the wing surface was analyzed by the FT-IR spectra.

\section{Evaluation of the Self-cleaning Performance}

The wing pieces were affixed to a glass slide with double-sided adhesive tape, and put on the sample table of OCA20. Five $\mathrm{mg}$ of $\mathrm{CaCO}_{3}$ particle was evenly spread on the discal cell of the wing. A water droplet from an injector fell on the $\mathrm{CaCO}_{3}$ area, the sample table was inclined $3^{\circ}$, the droplet flowed through the contaminated area. Using an electronic analytical balance (Shimadzu AUX-120, Japan), the mass of $\mathrm{CaCO}_{3}$ residual was measured, and the removal rate was calculated. 


\section{Results and Discussion}

\section{The Self-cleaning Performance of the Wing Surface}

Both the butterfly and the moth wing surface display outstanding self-cleaning performance. When the droplet flows over the wing surface, most $\mathrm{CaCO}_{3}$ particles are taken away. The removal rates are all over $80.0 \%$. The average removal rate is $88.0 \%$ (butterfly wing) and $87.7 \%$ (moth wing), respectively (Table 1).

Table 1. The CA, SA, removal rate of $\mathrm{CaCO}_{3}$ particle, roughness index $(R I)$ on the wing surfaces

\begin{tabular}{|c|c|c|c|c|c|}
\hline \multicolumn{2}{|c|}{ Species } & \multirow{2}{*}{$\begin{array}{c}\mathrm{CA}\left(^{\circ}\right) \\
152.4\end{array}$} & \multirow{2}{*}{$\frac{\mathrm{SA}\left({ }^{\circ}\right)}{2}$} & \multirow{2}{*}{$\begin{array}{c}\begin{array}{c}\text { Removal rate of } \\
\mathrm{CaCO}_{3} \text { particle }(\%)\end{array} \\
85.4 \\
\end{array}$} & \multirow{2}{*}{$\begin{array}{c}\begin{array}{c}\text { Roughness index }(R I) \\
\text { of wing surface }\end{array} \\
2.1 \\
\end{array}$} \\
\hline \multirow[t]{10}{*}{ Butterfly } & Antigius attilia & & & & \\
\hline & Araragi enthea & 153.1 & 2 & 83.6 & 2.1 \\
\hline & Artopoetes pryeri & 155.5 & 2 & 86.7 & 2.7 \\
\hline & Favonius aurorinus & 156.2 & 1 & 90.5 & 3.8 \\
\hline & Favonius orientalis & 148.3 & 3 & 88.3 & 2.8 \\
\hline & Japonica saepestriata & 152.6 & 1 & 91.8 & 3.5 \\
\hline & Neozephyrus japonicus & 150.7 & 3 & 88.2 & 2.8 \\
\hline & Neozephyrus taxila & 154.2 & 2 & 91.4 & 3.6 \\
\hline & Shirozua jonasi & 154.5 & 1 & 86.6 & 2.2 \\
\hline & Thecla betulae & 150.8 & 2 & 87.0 & 3.0 \\
\hline \multirow[t]{10}{*}{ Moth } & Cerura menciana & 153.6 & 1 & 92.5 & 3.5 \\
\hline & Clostera anachoreta & 152.3 & 2 & 87.8 & 2.6 \\
\hline & Hybocampa umbrosa & 154.7 & 1 & 91.6 & 3.6 \\
\hline & Lampronadata cristata & 150.4 & 2 & 90.3 & 3.2 \\
\hline & Lophocosma atriplaga & 152.9 & 4 & 82.4 & 1.7 \\
\hline & Nericoides davidi & 153.3 & 3 & 85.8 & 2.5 \\
\hline & Nericoides leechi & 152.8 & 4 & 82.7 & 2.6 \\
\hline & Paranerice hoenei & 154.5 & 2 & 88.1 & 2.8 \\
\hline & Peridea lativitta & 153.2 & 2 & 87.2 & 2.6 \\
\hline & Phalera assimilis & 151.6 & 2 & 88.9 & 3.0 \\
\hline
\end{tabular}

$$
R I=\sqrt{\frac{4 d^{2}}{e^{2}}+1},
$$

where $\mathrm{d}$ and e represent height and width of the longitudinal ridge, respectively [8].

\section{The Low Adhesive Superhydrophobicity of the Wing Surface}

The wing surfaces of the butterfly and moth exhibit superhydrophobicity. All the water CAs are over $150^{\circ}$, except Favonius orientalis $\left(148.3^{\circ}\right.$ ) (Table 1). Meanwhile, the wing surfaces have low adhesion, the water SA is so small (SA $1 \sim 3^{\circ}$ for butterfly, $1 \sim 4^{\circ}$ for moth) that even a very slight tilting of the wing is sufficient to cause the droplet to roll off. The wing surfaces are of low adhesive superhydrophobicity. The butterfly and moth wings have perfect superhydrophobic and self-cleaning surfaces.

\section{The Micro/nano Structure of the Wing Surface}

The butterfly and moth wing surfaces display similar micro/nano structures (Fig. 2). The micrometric scales constitute the primary structure. For the butterfly wing, the length of the scale is $57 \sim 124 \mu \mathrm{m}$, the width is $32 \sim 65 \mu \mathrm{m}$, the spacing is $56 \sim 90 \mu \mathrm{m}$ [Fig. 2(a)]. For the moth wing, the length of scale is $186 \sim 328 \mu \mathrm{m}$, the width is $64 \sim 125 \mu \mathrm{m}$, the spacing is 103 172 $\mu \mathrm{m}$ [Fig. 2(d)]. The submicrometric longitudinal ridges and lateral bridges on the scales constitute the secondary structure [Fig. 2(b), 2(e)]. The 
nano stripes on the longitudinal ridges and lateral bridges constitute the tertiary structure [Fig. 2(c), 2(f)].
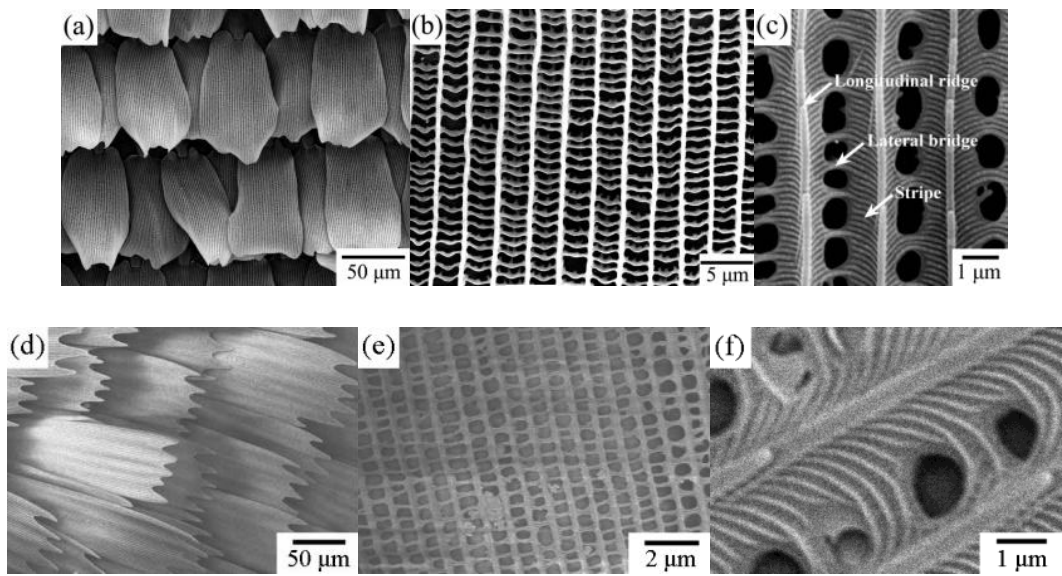

Figure 2. The hierarchical microstructure of the butterfly and moth wing surfaces (SEM)

(a) Primary structure (butterfly); (b) Secondary structure (butterfly); (c) Tertiary structure (butterfly); (d)

Primary structure (moth); (e) Secondary structure (moth); (f) Tertiary structure (moth).

\section{The Self-cleaning Mechanism of the Wing Surface}

The wing surfaces of butterfly and moth exhibit highly similar absorption characteristic of FT-IR spectra (Fig. 3).

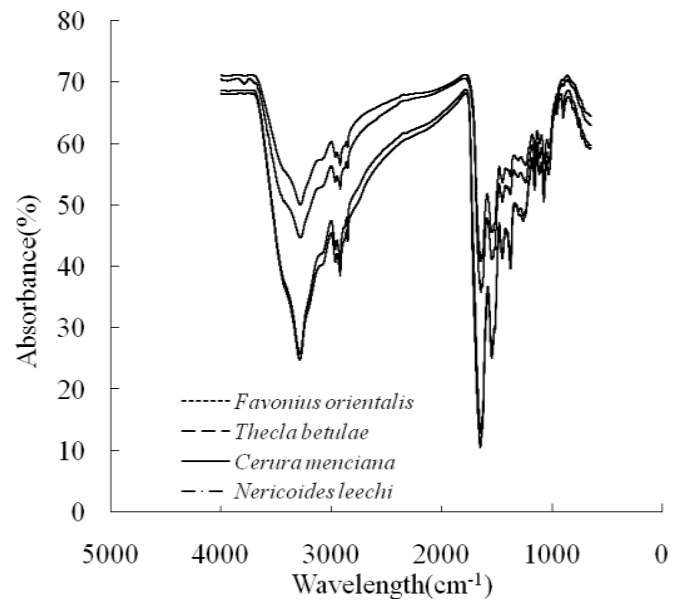

Figure 3. FT-IR spectra of moth and butterfly wing surfaces

For the butterfly wing, the absorption peaks are at 3261, 2944, 2876, 1650, 1534, $1383,1227,1147,1055 \mathrm{~cm}^{-1}$. For the moth wing, the absorption peaks are at 3294,2942 , $2881,1652,1531,1381,1230,1176,1071 \mathrm{~cm}^{-1}$ (Table 2). These absorption bands result from the stretching vibration, skeletal vibration, deformation vibration and in-plane bending vibration of the bases (e.g. $-\mathrm{CH}_{3},-\mathrm{CH}_{2},-\mathrm{C}-\mathrm{CH}_{3}, \mathrm{C}-\mathrm{H}, \mathrm{O}-\mathrm{H}, \mathrm{C}=\mathrm{O}, \mathrm{C}-\mathrm{O}, \mathrm{N}-\mathrm{H}$ ) in chitin, protein or fat [9]. Owing to the existence of hydrogen bond (H-bond), O-H peak is always rather wide. The absorption bands around 3294, 3261, 2944, 2942, 2881, 2876 $\mathrm{cm}^{-1}$ result from stretching vibration of $-\mathrm{CH}_{3},-\mathrm{CH}_{2}, \mathrm{C}-\mathrm{H}$ bases in chitin, protein or fat. The absorption band around 1652, $1650 \mathrm{~cm}^{-1}$ results from symmetrical stretching vibration of $\mathrm{C}=\mathrm{O}, \mathrm{C}-\mathrm{H}, \mathrm{N}-\mathrm{H}$ bases in chitin or protein. The absorption band around $1534,1531 \mathrm{~cm}^{-1}$ results from skeletal vibration of $\mathrm{C}-\mathrm{C}$ in chitin and deformation vibration of $\mathrm{C}=\mathrm{O}, \mathrm{C}-\mathrm{H},-\mathrm{C}-\mathrm{CH}_{3},-\mathrm{CH}_{2}$ bases in protein or fat. The absorption bands 
around 1383, 1381, 1230, $1227 \mathrm{~cm}^{-1}$ result from in-plane bending vibration of C-H base in chitin, protein or fat. The absorption bands around 1176, 1147, 1071, $1055 \mathrm{~cm}^{-1}$ arise from stretching vibration of $\mathrm{C}-\mathrm{O}$ base in chitin, protein or fat. The butterfly and moth wing surfaces are composed mainly of naturally hydrophobic material (intrinsic CA 95 $100^{\circ}$ ), which is the chemical foundation of the superhydrophobicity and self-cleaning property on the wing surfaces. However, much higher hydrophobicity can not be induced by the chemical composition alone.

Table 2. The characteristic peaks in FT-IR spectra of butterfly and moth wings

\begin{tabular}{|c|c|c|c|c|c|c|c|c|c|c|}
\hline \multicolumn{2}{|r|}{ Species } & \multicolumn{3}{|c|}{$4000 \sim 2500 \mathrm{~cm}^{-1}$} & \multicolumn{2}{|c|}{$\begin{array}{c}2500 \sim 1500 \\
\mathrm{~cm}^{-1} \\
\end{array}$} & \multicolumn{4}{|c|}{$1500 \sim 1000 \mathrm{~cm}^{-1}$} \\
\hline \multirow{11}{*}{ Butterfly } & Antigius attilia & 3264 & 2944 & 2876 & 1648 & 1535 & 1379 & 1227 & 1152 & 1057 \\
\hline & Araragi enthea & 3265 & 2943 & 2876 & 1653 & 1532 & 1385 & 1221 & 1145 & 1058 \\
\hline & Artopoetes pryeri & 3262 & 2944 & 2877 & 1651 & 1536 & 1383 & 1227 & 1148 & 1050 \\
\hline & Favonius aurorinus & 3261 & 2947 & 2875 & 1654 & 1535 & 1384 & 1224 & 1146 & 1051 \\
\hline & Favonius orientalis & 3255 & 2945 & 2877 & 1650 & 1532 & 1380 & 1228 & 1145 & 1058 \\
\hline & $\begin{array}{l}\text { Japonica } \\
\text { saepestriata }\end{array}$ & 3257 & 2945 & 2878 & 1650 & 1537 & 1387 & 1225 & 1154 & 1057 \\
\hline & $\begin{array}{l}\text { Neozephyrus } \\
\text { japonicus }\end{array}$ & 3259 & 2938 & 2872 & 1645 & 1535 & 1382 & 1229 & 1143 & 1052 \\
\hline & Neozephyrus taxila & 3268 & 2943 & 2869 & 1652 & 1528 & 1384 & 1227 & 1144 & 1050 \\
\hline & Shirozua jonasi & 3261 & 2946 & 2874 & 1648 & 1530 & 1386 & 1226 & 1145 & 1059 \\
\hline & Thecla betulae & 3256 & 2942 & 2881 & 1651 & 1538 & 1378 & 1231 & 1145 & 1053 \\
\hline & Average & 3261 & 2944 & 2876 & 1650 & 1534 & 1383 & 1227 & 1147 & 1055 \\
\hline \multirow{11}{*}{ Moth } & Cerura menciana & 3301 & 2945 & 2884 & 1652 & 1530 & 1382 & 1231 & 1175 & 1073 \\
\hline & Clostera anachoreta & 3286 & 2939 & 2878 & 1647 & 1528 & 1384 & 1236 & 1176 & 1071 \\
\hline & $\begin{array}{l}\text { Hybocampa } \\
\text { umbrosa }\end{array}$ & 3295 & 2944 & 2882 & 1657 & 1532 & 1383 & 1229 & 1175 & 1068 \\
\hline & $\begin{array}{l}\text { Lampronadata } \\
\text { cristata }\end{array}$ & 3287 & 2940 & 2884 & 1654 & 1525 & 1383 & 1233 & 1181 & 1072 \\
\hline & $\begin{array}{l}\text { Lophocosma } \\
\text { atriplaga }\end{array}$ & 3294 & 2948 & 2878 & 1653 & 1537 & 1380 & 1228 & 1174 & 1075 \\
\hline & Nericoides davidi & 3306 & 2937 & 2881 & 1651 & 1532 & 1381 & 1227 & 1175 & 1069 \\
\hline & Nericoides leechi & 3291 & 2946 & 2879 & 1650 & 1534 & 1382 & 1232 & 1176 & 1072 \\
\hline & Paranerice hoenei & 3299 & 2939 & 2880 & 1649 & 1530 & 1380 & 1229 & 1177 & 1071 \\
\hline & Peridea lativitta & 3289 & 2941 & 2879 & 1650 & 1529 & 1379 & 1230 & 1176 & 1067 \\
\hline & Phalera assimilis & 3292 & 2942 & 2883 & 1652 & 1531 & 1378 & 1226 & 1173 & 1070 \\
\hline & Average & 3294 & 2942 & 2881 & 1652 & 1531 & 1381 & 1230 & 1176 & 1071 \\
\hline
\end{tabular}

Due to the rough structures on the wing surface, most contaminating particles settle on the tips of microtextures, the actual contact area between particle and microstructure is very small. The adhesive force between particles and water droplet is much larger than that between particles and microstructure, thus the particles can be "trapped" and taken away easily by the rolling droplet. The removal rate of contaminating particle has no significant correlation $\left(\mathrm{R}^{2}<0.1\right)$ with the scale parameters (length, width, spacing) or the longitudinal ridge parameters (height, width, spacing), but has significant correlation $\left(\mathrm{R}^{2}=0.8385\right.$ for butterfly, 0.8155 for moth) with roughness index $(R I)$ of the wing surface (Fig. 4). RI, the magnitude of surface roughness, is the ratio of the real area to the geometry projection area. The superhydrophobicity and self-cleaning characteristic of the wing surface ascribes to the coupling effect of hydrophobic material and rough structure. The self-cleaning function endows butterfly and moth with the ability to lighten body burden, decrease drag, increase flight efficiency and optimize energy budget. Thus, they can get more opportunities to survive. 

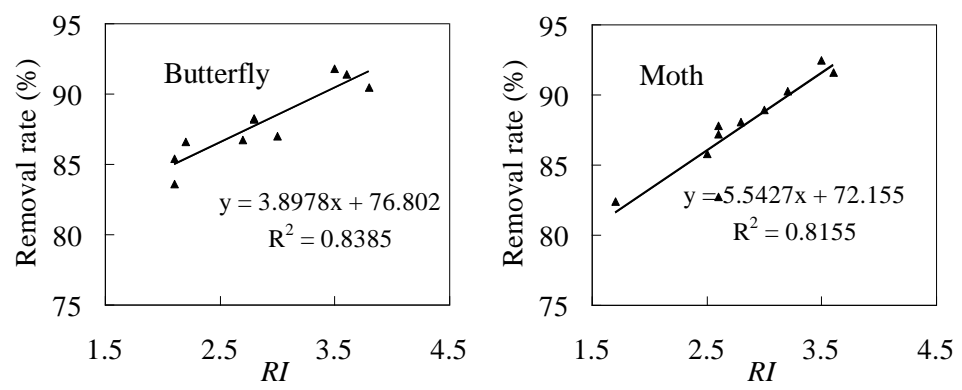

Figure 4. Relationship between the removal rate of $\mathrm{CaCO}_{3}$ particle and roughness index (RI) of the wing

\section{Summary}

The wing surfaces of butterfly and moth in Lepidoptera have similar chemical composition, multiple-dimensional microstructure, wettability and self-cleaning characteristic, despite the different taxonomic positions, morphological features and living habits. The wing surface is of low adhesion (SA $1 \sim 4^{\circ}$ ) and superhydrophobicity (CA 148.3 156.2 $2^{\circ}$. The removal rate of $\mathrm{CaCO}_{3}$ contaminating particle from the wing surface is averagely $88.0 \%$ (butterfly wing) and $87.7 \%$ (moth wing). There is a good positive correlation $\left(\mathrm{R}^{2}=0.8385\right.$ for butterfly, 0.8155 for moth) between particle removal rate and roughness index of the wing surface. The excellent self-cleaning property of the wing surface ascribes to the coupling effect of material element and structural element. The wings of Lepidoptera insect can be used as biomimetic templates for preparation of biomedical functional material.

\section{Acknowledgement}

This work was financially supported by the National Natural Science Foundation of China (Grant No. 31671010), the Natural Science Foundation of Jilin Province, China (Grant No. 201115162) and the Innovative Program for Postgraduate Students of Changchun Normal University (Grant No. cscxy2015007, cscxy2017003, cscxy2017006). Dr. Prof. Gang Sun is the corresponding author of this paper.

\section{References}

[1] S.T. Wang, L. Jiang, Definition of superhydrophobic states, Adv. Mater. 19 (2007) 3423-3424.

[2] X. Yao, Y.L. Song, L. Jiang, Applications of bio-inspired special wettable surfaces, Adv. Mater. 23 (2011) 719-734.

[3] X.J. Feng, L. Jiang, Design and creation of superwetting/antiwetting surfaces, Adv. Mater., 18 (2006) 3063-3078.

[4] L. Feng, S.H. Li, Y.S. Li, H.J. Li, L.J. Zhang, J. Zhai, Y.L. Song, B.Q. Liu, L. Jiang, D.B. Zhu, Super-hydrophobic surfaces: from natural to artificial, Adv. Mater. 14 (2002) 1857-1860.

[5] L. Feng, Y.A. Zhang, J.M. Xi, Y. Zhu, N. Wang, F. Xia, L. Jiang, Petal effect: A superhydrophobic state with high adhesive force, Langmuir 24 (2008) 4114-4119. 
[6] Y. Fang, G. Sun, Q. Cong, G.H. Chen, L.Q. Ren, Effects of methanol on wettability of the non-smooth surface on butterfly wing, J. Bion. Eng. 5 (2008) 127-133.

[7] G. Sun, Y. Fang, Q. Cong, L.Q. Ren, Anisotropism of the non-smooth surface of butterfly wing, J. Bion. Eng. 6 (2009) 71-76.

[8] Y. Fang, G. Sun, T.Q. Wang, Q. Cong, Hydrophobicity mechanism of non-smooth pattern on surface of butterfly wing, Chin. Sci. Bull. 52 (2007) 711-716.

[9] X.J. Wang, Q. Cong, J.J. Zhang, Y.L. Wan, Multivariate coupling mechanism of Noctuidae moth wings' surface superhydrophobicity, Chin. Sci. Bull. 54 (2009) 569-575. 